\title{
IMPLEMENTATION OF SCHOOL MANAGEMENT INCLUSIVE EDUCATION INSTITUTIONS
}

\author{
Dian Fajarwati \\ LPPKS, Ministry of Education and Cultures, Indonesia \\ dianfajarwati@gmail.com
}

\begin{abstract}
The article entitled Implementation of School Management of Inclusive Education Institutions examines the implementation of school management that provides educational services appropriate to children's learning needs. The school of inclusive education is a manifestation of the implementation of the mandate of Article 5 (1) of the National Education Law number 20 of 2003 which stipulates that for students who have special needs should be given special services. Permendiknas number 70 of 2009 which is valid since October 22, 2009 on Inclusive Education for Students Who Have Abnormalities And Have The Potential Of Intelligence And /or Special Talent. Based on the legal basis, the management of inclusive education providers should be managed by taking into account the specific needs of learners (children of crew). The challenges and obstacles that arise in the management of inclusive education providers come from internal and external. The appropriate and appropriate alternative school management solutions for inclusive and appropriate education providers are obtained by developing curriculum management, teacher educator management (PTK), and management of school infrastructure that can accommodate the needs of both children with special needs and regular children who will ultimately support the success of education National unity and justice.
\end{abstract}

Keywords: implementation, management, school, inclusive education

\section{Background}

\section{INTRODUCTION}

Education is a right for every human being, regardless of circumstance and whatever condition it is born in the world. All countries have an obligation to ensure that all their peoples can receive equal education. The Government of the Republic of Indonesia in this case the Ministry of Education and Culture of Indonesia issued Permendiknas Number 70 of 2009 on Inclusive Education for Students Having Disabilities and Potential of Intelligence and / or Special Talent.

Since the emergence of the Regulation of the Minister of National Education number 70 of 2009 dated October 22, 2009, deyure in the national education environment recognized the diversification of educational services, so for those who have special needs must receive special learning services and use a special curriculum as well. The same support also emerged from the provisions of Article 5 (1) of the Law on National Education System number 20 of 2003 which stipulates that for students who have special needs should be given special services.

Inclusion schools are schools that provide educational and learning services regardless of the physiological state of the child. All students who apply for education will be accepted either regular or special needs children (disabilities or special intelligent children). The school provides a friendly learning service for all of its students. Inclusive school program developed by the Ministry of Education and Culture of Indonesia in accordance with the Law No. 20 of 2003 on the National Education System is defined as a conscious and planned effort to create an atmosphere of learning and learning process so that learners are actively able to develop their potential to have the power Spiritual, religious, self-control, personality, intelligence, noble character, and skills needed him, society, nation and state.
Purpose of Basic Education according to Government Regulation number 28 year 2000, chapter II article 3 is to provide basic ability to learners to develop their life as person, member of society, citizen and member of human being and prepare learners to follow secondary education. Inclusive schools are scattered in every sub-district for primary and secondary education levels for secondary education. The Head of the Education Office gives a letter of appointment to the designated school to implement the inclusive school program. But the implementation of the inclusive school program still does not look maximal in school. School management became the problem of almost all schools of inclusion in public schools. The principal is constrained by the teacher's ability to serve the needs of inclusive children in the classroom, while the classroom teacher also has to function as an educator and instructor who must be able to serve all the characters and learning styles of learners. As a result, children with special needs can not be served maximally.

Implementation of inclusive education in public schools requires a comprehensive thinking related to the readiness of schools in managing the realization of educational services that can accommodate the needs of children. This article focuses on school management especially curriculum management, teacher educator management, and management of school infrastructure as a supporting factor to address challenges and expectations in the implementation of inclusive education in public schools. It is based on the premise that inclusive education in public schools requires special curriculum management, which provides a clear learning service for children with special needs in the school. In addition, the management of educational personnel also plays a very important role in the implementation of inclusive schools. Because the educator is the core of the implementation of the learning process in school. Educators must understand how to provide services to 
students according to their individual learning needs. Based on this, the researcher considers important to realize the appropriate and appropriate school management model in implementing inclusive education in public schools to answer the challenge and expectation of inclusive education implementation.

\section{Problem Focus}

Based on the above background, the focus of the problem from this research is as follows:

1. What are the challenges and obstacles faced by the school of inclusive education providers?

2. How are alternative solutions to overcoming the challenges and constraints faced by schools of inclusive education providers?

3. What is the proper and appropriate implementation of school management for the school of inclusive education providers?

\section{Research Objectives}

Based on the above background, the purpose of this study is as follows:

1. To find out the challenges and constraints faced by schools of inclusive education providers;

2. To find alternative solutions to address the challenges and constraints faced by schools of inclusive education providers;

3. To describe Implementation of appropriate and appropriate school management for inclusive education providers.

\section{RESEARCH METHODS}

This research uses descriptive qualitative approach. The meaning of qualitative research is research that intends to understand the phenomenon of what is experienced by the subject of research holistically, and by way of description in the form of words and language, in a special context that is natural and by utilizing various scientific methods (Moleong, 2007: 6). The type of qualitative descriptive research used in this study is intended to obtain information on the implementation of school management of inclusive education providers.

The study was conducted in two schools of inclusive education providers (Kota Surakarta and Kendal District) of Central Java Province. Researchers take data by conducting interviews to the Principal, Curriculum and Learning Affairs, Classroom Teachers, Students, and Education Personnel (TU, librarian, and laboratory). It also conducts observations and document studies related to the focus of the problem. The data analysis technique uses the following steps: data collection, data reduction, data display, and verification and confirmation of conclusions (Bungin, 2003:70).

\section{RESULTS AND DISCUSSION}

Barriers and Challenges Implementing School Management of Inclusive Education Organizer

1. Obstacles

a. Principal

- Lack of understanding of inclusive education management mechanisms in public schools;
- Less in providing socialization both to teachers and the community about the importance of providing child-based services, especially children with special needs;

- lack of consistent commitment in providing educational services that favor the needs of children of inclusion, sometimes just the idea of rejecting students coming from the principal on the grounds do not want to burden the work of teachers.

\section{b. Teachers / Educators}

- Lack of understanding of learning services to children with special needs;

- Lack of scientific knowledge of inclusive education services;

- Commitment and integrity that is consistent in serving children with special needs who learn with regular children

\section{c. Parents / guardians}

- Parents / guardians of children of inclusion (with special needs) feel ashamed to send their children to school regularly, worried about being mocked by regular children and will result in his child becoming inferior or inferior;

- Parents / guardians of regular children protest for fear that their children are disturbed to learn because they have to be mixed with inclusion children (special needs).

d. Financing

- Provision of facilities and infrastructure to support the inclusive education learning process requires funds that are not small. While the school operational assistance fund (BOS) is certainly not able to meet the needs of children's learning facilities inclusion

\section{Challenge}

The implementation of inclusive education in public schools has challenges to face in the present and future, both internally and externally. Here are some of the challenges faced by schools of inclusive education providers in public schools:

\section{a. Internal}

Internal challenges arise from within the school itself: the commitment of the Principal and the educator / teacher, the ability to understand the concepts of inclusion children, the unresolved curriculum for implementing education and learning in inclusive schools, the implementation of learning to serve the children of inclusion with regular children, and the lack of supporting infrastructure Need characteristic of children inclusion in school.

\section{b. External}

External challenges arise from society in this case parents. Both parents whose children suffer special needs as well as parents from regular children. Parents of children with special needs will generally be anxious and worried if their children will be inferior and can not adapt to the environment of regular children. While parents of regular children have a concern that their children will be disturbed learning if mixed with children with special needs. 


\section{Alternative Solutions Overcoming Challenges and Constraints}

Inclusion schools are schools that provide learning services for children with special needs to learn together with regular children in the school community, accommodating all students in the same classroom by taking into account the needs of each child in order to optimize their skills and abilities. In addition, inclusion schools are a place for every child to be accepted into a class, responding to diversity through a curriculum that fits the needs of each child and interacts with the community.

The right and appropriate solution for holding inclusive education in public schools is to develop a model of school management in the implementation of inclusive education in public schools so that they can be understood and easily implemented by school principals and other education policy stakeholders. The design of school management model in the implementation of inclusive education in public schools the authors describe as follows:

\section{Curriculum Management}

The curriculum in schools that provide inclusive education is designed by taking into account the national curriculum with the modification of learners' self-needs according to their talents, interests, potentials, and characteristics. Self-need for inclusive children (need special) must be clearly seen classification type and character ketunaan or special needs. For example, blind, blind, deaf, speech, or autistic children even in children with special intelligence category or special talent (CI / BI).

Schools also have Minimum Exhaustiveness Criteria (KKM) that are not the same between regular students with inclusive students by type / character needs. Schools should establish active communication to parents of parents, especially inclusive students so that parents know the learning needs of children with special needs. Schools facilitate educators / teachers in preparing learning tools that can be seen every student's learning service that is regular or special (inclusion).

\section{Management of Teachers of Education Personnel}

Educators and education personnel are at the core of the learning process. Educators / teachers hold a vital role to educate the nation's children. Inclusion education in public schools requires a patient, patient, committed, and student-friendly teacher / teacher. Once vital the role of educators for schools, then inclusive schools should program training on how to teach in inclusive classes. Because today many teachers / teachers found in inclusion schools are less understanding about the learning process that is able to accommodate all students' learning modalities. Educators / teachers are trapped in the teaching style to be followed by the students. Though it should be teachers who must follow and adjust to the learning style of students.

Often found in inclusion schools, it refuses to have a child with special needs on the grounds that it will be inconvenient for the school in this case the teacher in handling the learning process in the classroom, besides the teacher also feel the hassle if there are regular students who feel disturbed by the presence of children with special needs in Class so as to disturb the stability and comfort of student learning.

Faced with the above reality, the school at the beginning of the school year must socialize to the entire school community to serve the child regardless of the child's situation. Because basically the school is a place to learn. Schools should provide training or knowledge-sharing and learning techniques on how to serve the learning style of students with special needs to all teachers in the school.

Educators in public schools conducting inclusive education should be able to create a harmonious atmosphere for all students in the classroom where there is a child of inclusion (special needs) to avoid disputes between students and feelings of discomfort. Educators should give understanding to regular students to respect and appreciate inclusive (special needs) children's shortcomings so that school atmosphere becomes harmonious and there is no distinction. Because this is by most inclusive schools the organizers are often a serious reason.

\section{Management of School Facilities and Infrastructure}

One of the factors of school success is the existence of facilities and infrastructure that support. Likewise with schools of inclusive education providers. Governments should allocate budgets to accommodate the needs of inclusive children. These include the facilities and infrastructure that should be provided in public schools that provide inclusive education:

a. Assessment tool for the blind, deaf and blind children; To determine the level of deficiencies and abnormalities experienced by inclusive students;

b. Learning / academic tools for disabled children;

c. Student creativity tool according to type of disability.

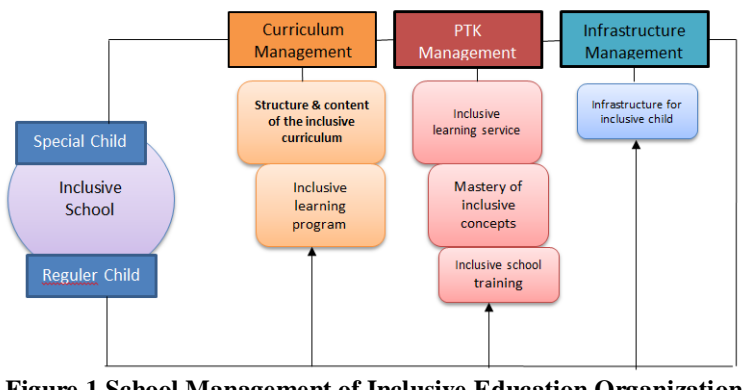

Figure 1 School Management of Inclusive Education Organization 
Based on the picture above can be explained that the school of inclusive education to serve children with various needs of children with special needs (special needs) and regular children (normal). This should be a concern of the school especially in serving the process of education and learning in schools. Therefore schools of inclusive education providers should prepare the maximum school management as follows:

\section{Curriculum Management}

The curriculum management should be tailored to the structure and curriculum content that can accommodate the needs of the learners (both children with special needs and regular children). In addition, the school must also design a learning program that can serve the needs of students in accordance with the type of child (special and regular), so that learners feel comfortable in learning according to their individual learning needs.

\section{Management of PTK}

Schools of inclusive education require educators and education personnel who truly understand the learning needs of learners. Educators for children with special needs should understand the psychology of child development and the specificity of children with special needs. If the school does not have an educator without a special education background, then the school must cooperate with educators in Special School (SLB). It is intended that learners get the right education and proper teaching but they can still socialize and get along with other regular kids. Educators in inclusive education providers should have a strong and clear concept of the concept of inclusive education. Schools of inclusive education should also routinely educate and train on inclusive education services to train pedagogical and professional competence of educators in providing learning services.

\section{Management of School Infrastructure Facility}

Schools of inclusive education in supporting the learning process for children with special needs and regular children (normal) must also provide school infrastructure that fits the physical needs of children. For example provided roads / access for students with blind people following books using braille, and so forth.

School infrastructure of the providers of inclusive education should be managed well from the identification of needs tailored to the type of special needs of learners for children of crew. Once the needs are identified, the next budget is procured in the RKAS

\section{Description of the Implementation Implementation School Implementation School Implementation}

Inclusive Education is indispensable in every region of Indonesia. In accordance with Permendiknas RI No. 70 of 2009 on inclusive education Article 6, namely: District / municipal governments ensure the implementation of inclusive education in accordance with the needs of learners, District governments ensure the availability of inclusive education resources in designated educational units, the Government and provincial governments assist in the availability of educational resources inclusive.

Based on the above regulations, local governments in Indonesia should ensure the implementation of inclusive education in their regions. There is at least one school of inclusive education in one city. This is because education is very important for all circles. For administrative and coaching purposes, as well as fluency in the implementation of inclusive education, schools need to follow the following procedures:

1. Schools that will receive special needs children submit proposals for the implementation of inclusive education to the District Education Office. While schools that already have special needs learners report the implementation of inclusive education to the District Education Office.

2. District / City Education Office to follow up proposals / reports from the school concerned to the Provincial Education Office.

3. District / City Education Office and Provincial Education Office shall visit to the school concerned.

4. Provincial Education Office establishes the school concerned as the provider of inclusive education by issuing its letter of appointment, with copies to the District / City Education Office, and the Directorate of Special School Development.

The criteria of the candidates for the school of inclusive education are:

1. School readiness to organize inclusive education programs (school principals, school committees, teachers, learners, and parents).

2. There are children with special needs in the school environment.

3. Available special education teachers (GPK) from PLB (permanent school teachers or teachers seconded from other institutions).

4. Commitment to the completion of compulsory education.

5. Having a network of cooperation with other relevant institutions.

6. Available supporting facilities that are easily accessible to all children.

7. Schools have received socialization on inclusive education.

8. The school has been accredited.

9. Meets the specified administrative procedures.

According to Suparno et al (2007:23) the school of inclusive education must meet certain requirements, including: the existence of special needs students, consistent to inclusive education, school management, facilities and infrastructure and manpower.

Inclusive Education is a system of educational services that requires children with special needs to study in nearby schools in regular classes with their age friends (Sapon-Shevin in Neil 1994: 56). Schools of inclusive education are schools that accommodate all students in the same class. The school provides a 
decent, challenging education program, but adapts to the abilities and needs of each pupil and the help and support that teachers can make for successful children (Stainback, 1980).

This study focuses on how to manage inclusive education schools appropriately and in accordance with the needs of all learners. The focus of school management on the management of curriculum and learning, management of educational personnel, and management of school infrastructure. The following is a description of the implementation of school management of inclusive education providers as follows:

\section{a. Management of Curriculum and Learning for} Inclusive Education Schools

In the provision of learning services for inclusive students along with their curriculum structures the first important step to take is adjustment to the provisions applicable to inclusive students and their character. Treatment that is less than the maximum and inconsistent with the character of inclusive students has been caused by misconception and lack of fit between the demands that should be with the reality of the implementation in the classroom. This causes the treatment and learning service to inclusion students to be less than the maximum and even less useful for the development of its potential.

The implementation of inclusion classroom learning is just a label that has no effect on learning outcomes and high-level thinking if implementation in inclusion classes is treated the same as regular classes, both in the learning model and the curriculum (Baska, 2005).

Research conducted by Swiatek and Benbow (1991) concluded that the correct use of inclusive learning service model will be able to develop positive knowledge and decrease the negative effects of social and emotional aspects. Therefore, the application of learning for inclusive students is not harmful for the emotional social growth if done well. Similar research findings were also reported by Robinson and Janos (1989) who concluded that in inclusion services would not undermine student inclusion class participants if done in accordance with applicable provisions.

The current curriculum in Indonesia determines that the contents of the curriculum menu enacted in schools must be developed from the content standards as set out in Permendikbud number 103 of 2014 so that the different curriculum between schools is only distinguished by indicators developed in accordance with the character of the school students concerned, the local needs As well as the benefits to be achieved (PP 19/2007 on Management Standards). Under these provisions, the inclusion school curriculum also follows a modified curriculum pattern that relies on content standards. The distinction between the inclusion curriculum and the regular / general curriculum is the depth and breadth of the content. Although the pattern is so but in reality the curriculum of inclusive students remains the same as the regular class. That way the contents of the school curriculum inclusion menu to be the same with the format of the regular class that should not be equated considering the students served have different levels of maturity, motivation, and ability. This step is very risky ie the occurrence of material inadequacy for inclusive students resulting in inclusive student material can not meet from the demands of competence.

Theoretically, the curriculum devoted to inclusion students who have the character of intelligence and learning speed should not be the same as the curriculum given to regular students because the weight and depth do not meet their character (Tomlinson 2006. Renzulli 2004. Reis. Joan 2004) .

\section{b. Management of Teachers in Implementation of Inclusive Education in Public Schools}

With the occurrence of Permendiknas number 70 of 2009 effective from October 22, 2009 then all schools of inclusive class providers must meet the demands of the new legislation. In practice there is a gap between juridical and reality demands on the ground. The problem is not only in the management of the curriculum and its supporting tools but the inability of educators / teachers to provide learning services to inclusive students.

The successful implementation of inclusive education in public schools is highly dependent on the ability of the Teachers (Teachers). Educators must have a high commitment and breadth of knowledge about inclusive education in serving students who have unequal character and abilities.

The provision of inclusive educational services that are varied in nature are based on the desire to present treatments of educational services that are able to reach individual needs and are contextual. Theoretical amplifier in the latest learning environment related to learning service is Reigeluth (1999: 19) which is very popular in American instructional design today. He asserted that the paradigm of learning now leads to a shift from the standardization pattern to customization. The pattern requires that the organization must follow the rhythm and character of the learners. He emphasized that learning is not only focused on focus on presenting material but is focused on making sure that learner's needs are met.

According to Lapsky and Gardner (in Fredericson and Cline 2002: 66) inclusion is defined as the provision of services to students with disabilities, including those with severe disabilities in general education classes, accompanied by support services and additional assistance needed for children and teachers to succeed in Academic, behavioral and social participation.

Inclusion itself may mean the adoption of children who have barriers to the curriculum, the environment, social interactions and self-concept (vision-mission) of the school (Smith, 2006: 45).

An educator in an inclusive school must be patient and patient in guiding and serving students with special needs who study together with regular students. Educators must understand the psychological ability, character, and development of children with special needs. Educators should not be forced to have special needs children have the same abilities as regular children. 


\section{c. Management of Facilities and Infrastructure for Schools of Inclusive Education in Public Schools}

School facilities and infrastructure is a contributing factor to the success of education and learning processes in schools. Adequate facilities and infrastructure will make the atmosphere of education and learning to be 'live' and enjoyable.

Inclusive education in public schools require the readiness of facilities and infrastructure that support the inclusion of children's needs (special needs). For example for blind children, schools should have the facility of books and reading using Braille letters, the school must also provide a friendly and convenient way for visually impaired students access (small rocky road). Furthermore, for children with disabilities, schools provide a playroom to eliminate boredom and train the motor physically mentally disabled children.

So important supporting facilities and infrastructure for the continuity of education in schools, especially public schools are defined as inclusive schools. Because according to Shaffer (2002: 593) inclusive education is the practice of merging education for special needs students into regular classes. This is a better thing than putting them into separate specialized education.

\section{CONCLUSIONS AND EXPECTATIONS AUTHOR}

\section{Conclusion}

Challenges and obstacles in the implementation of inclusive education are the joint responsibility of the Government, Education Office, School Principals, educators / teachers, parents, and the community. Therefore, comprehensive management is needed from curriculum, teacher educator, and school infrastructure.

The curriculum in inclusion schools should take into account the diverse needs of diverse children, not biased the ability of regular children with children with special needs so that learning planning prepared by teachers should be able to accommodate it. Implementation of learning should be able to accommodate all the needs of students both regular and special. While educators in inclusive schools should be able to embrace all students without distinguishing the physical state of the child. Protect the weak and create a friendly atmosphere in learning. Educators must be able to build mutual respect among students, so as to create a family atmosphere in the classroom. School infrastructure needs to be able to serve the needs of special children ranging from childhood detection tools, learning tools, and creativity builders in accordance with the character / type of inclusion childhood.

\section{Author's Expectations}

In 2008 s.d. 2010 the author has ever developed inclusive schools in SMP Muhammadiyah in a district in Central Java with independent path without the help of funds from the Government. All done with the call of conscience that all children are entitled to a decent education in humane and dignified without distinguishing the physical condition of the child. Together with children with special needs will actually increase gratitude towards Allah SWT. Serving children with special needs sincerely will increase the confidence of the child until it will be able to maximize their skills very rapidly. Not much hope from the author with the existence of inclusion schools, as follows:

a. Expectations for Inclusive Schools

1. Grow the confidence of children with special needs in associating with his friends

2. Cultivate the emotional social soul positively that they have the same rights as regular children

3. Cultivate the spirit of the life of the child with special needs that they are always in the midst of those who love and love him

4. Growing achievement because it is believed not human who has no potential, although its potential is not the same among humans. But with the affection that grows in the school environment, the child's talent will develop and give birth to a brilliant achievement in accordance with its uniqueness.

\section{b. Hope for Government}

1. Jer Basuki Mawa Bea, meaning the government can allocate funds for the implementation of the inclusive school program, because children with special needs require special assistance and services as well. Both learning services and school infrastructure services

2. Publication support to touch the lower community with the intention that parents who have children with special needs do not hesitate and not ashamed to send their children in public schools in order to blend together regular children.

\section{REFERENCES}

[1] _ 1991, The school wide Enrichment Model: A Comprehensive Plan for The development of Creative Productivity. London: Allyn and bacon.

[2] . (Editor: Denis \& Mrs. Enrica). 2012. Inclusive School. Bandung: Nuance

[3] _ 1986. The Schoolwide Enrichment Model: A Comprehensive plan for educational Excellence. Manfield Center. CT: Creative Learning Press.

[4] _. Enriching Curriculum for All students. Thousand Oaks CA: Corwin Press.

[5] _ 2003. What matter in Curriculum for Giftedlearning; Reflections non Theory, research and Practices. In Colangelo \& CA Dorris, Handbook of Gifted Education. Ny: Allyn \& Bacon.

[6] — 2006. Comprehensive Curriculum for Gifted Learner. Boston: Pearson Education.Inc.

[7] Carol A. Tomlinson. 2004. Differentiation For Gifted and Talented Students. CA: Corwin Press.

[8] Charles Reigeluth, 1999. Instructional- Design Theories and Models Volume II A New Paradigm of Instructional Theory. London: Lawrence Erlbaum Associates Publishers.

[9] Eko Suprianto, 2009. Technical Guidance of Curriculum Development for educational services of students with special needs. Jakarta: Directorate of Special School Development 
[10] Joyce Van Tassel Baska, 2005. Acceleration Strategies for Teaching Gifted Learner. Texas: Prefrock.

[11] Ministry of National Education, 2009. Decree of the Minister of National Education number 70 of 2009 on the implementation of special education.

[12] Purnama, Anindya. (2014). School of Inclusion and Crew. [Online] source: accessed September 9, 2016

[13] Raye, Holy Ramadhani. (2012). General Guidelines for Inclusive Education. [Online] source: Retrieved 9 September 2016

[14] Renzulli, J.S. 1977. The Enrichment Traid Model: A Guide for Developing Defensible programs for the Gifted. Mansfield Center. CT: Creative Learning Press.

[15] Robinson, A. 2002. Differentiation for talented learners: what are some indicators? Understanding our gifted, 15 (1) 3-5).

[16] Shaffer, D.R. 2002. Childhood and Adolescence: Developmental Psychology. (6 ed.). USA: Wadsworth Group.

[17] Smith J. David. 2006. Friendly School Inclusion for All. Bandung: Nuansa Publisher.
[18] Sternberg, R. 1985. Beyond IQ. England: Cambridge University Press.

[19] Suparno. 2007. Standard Operating Procedures for Inclusive Education. Jakarta: Directorate of Special School Development, Directorate General of Mandikdasmen, MoNE.

[20] Tilstone, C. Penny Lacey, 2000. Pupils with Learning Difficulties in Mainstream School. London: David Fulton Publisher

[21] Tomlinson, C.A. 2000. Leadership for differentiating school and Curriculum. Alexandria: ASCD.

[22] Van Tassel Baska, 1988. Execellence in Education Gifted \& Talented Learners. Denver, CO. Love Publishing.

[23] Winebrenner, Susan. 2001. Teaching Gifted Kids in The Regular Classroom. MN: Free Spirit Publishing

[24] Wulandari, Asrul. 2013. Model And Curriculum Inclusive Education [online] Source: downloaded September 